\title{
Stimulated Arachidonate Metabolism during Foam Cell Transformation of Mouse Peritoneal Macrophages with Oxidized Low Density Lipoprotein
}

\author{
Masayuki Yokode, Toru Kita, Yoshiharu Kikawa, Toshiya Ogorochi, Shuh Narumiya, and Chuichi Kawai \\ Third Division, Departments of Internal Medicine and Pharmacology, Faculty of Medicine, Kyoto University, Kyoto, Japan; and \\ Department of Pediatrics, Fukui Medical College, Fukui, Japan
}

\begin{abstract}
Changes in arachidonate metabolism were examined in mouse peritoneal macrophages incubated with various types of lipoproteins. Oxidized low density lipoprotein (LDL) was incorporated by macrophages and stimulated macrophage prostaglan$\operatorname{din} \mathrm{E}_{2}\left(\mathrm{PGE}_{2}\right)$ and leukotriene $\mathrm{C}_{4}$ syntheses, respectively, 10.8- and 10.7-fold higher than by the control. Production of

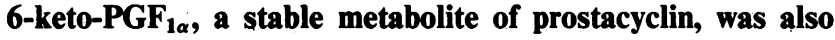
stimulated. No stimulation was found with native LDL, which was minimally incorporated by the cells. Acetylated LDL and beta-migrating very low density lipoprotein ( $\beta$-VLDL), though incorporated more efficiently than oxidized LDL, also had no stimulatory effect. When oxidized LDL was separated into the lipoprotein-lipid peroxide complex and free lipid peroxides, most of the stimulatory activity was found in the former fraction, indicating that stimulation of arachidonate metabolism in the cell is associated with uptake of the lipoprotein-lipid peroxide complex. These results suggest that peroxidative modification of LDL could contribute to the progression of atheroma by stimulating arachidonate metabolism during incorporation into macrophages.
\end{abstract}

\section{Introduction}

One of the initial events of atherosclerosis shown in animal experiments is the migration of circulating monocytes into the subendothelial space and their development into macrophages $(1,2)$. The intimal macrophages incorporate lipids into the cell body and eventually get converted into lipid-laden foam cells, which are characteristically found in the early stage of atheroma $(2,3)$. However, matured macrophages have only a limited number of classical low density lipoprotein (LDL) receptor, and take up native LDL at a very low rate, which is insufficient to cause foam cell transformation in vitro $(1,4,5)$. Therefore investigators have been attracted to other mechanisms of incorporation and metabolism of lipoproteins in macrophages. These cells have been reported to efficiently incorporate beta-migrating very low density lipoprotein $(\beta$ -

Address reprint requests to Dr. Kawai, Third Division, Department of Internal Medicine, Faculty of Medicine, Kyoto University, $54 \mathrm{Ka}$ wara-cho Shogoin, Sakyo-ku, Kyoto 606, Japan. 1987.

Received for publication 28 July 1986 and in revised form 6 October

J. Clin. Invest.

(c) The American Society for Clinical Investigation, Inc.

0021-9738/88/03/0720/10 \$2.00

Volume 81, March 1988, 720-729
VLDL) ${ }^{1}(6)$ and VLDL from the Watanabe heritable hyperlipidemic rabbits, an animal model for familial hypercholesterolemia (7-9) via a specific receptor, the $\beta$-VLDL receptor. In addition, macrophages were also demonstrated to incorporate certain types of chemically modified LDL. This pathway was first shown for acetylated LDL (acetyl-LDL) and the receptor is called the acetyl-LDL receptor $(4,5)$. Although the discovery of this pathway appeared to explain the paradox of macrophages in atherogenesis, a naturally occurring modified form of LDL has not yet been identified in the body. Recently oxidized LDL, in which acyl chains are peroxidized, has been reported to be efficiently taken up by macrophages at least in part by way of acetyl-LDL receptor (10-12). Because lipid peroxidation has been suggested to be involved in atherogenesis by pathological or epidemiological investigation $(13,14)$, oxidized LDL is considered as a candidate for an example of naturally occurring, modified LDL.

While foam cell transformation of macrophages has been indicated to be one of the key events of atheroma formation, it has not been clarified yet whether it is only a process of accumulation of the lipid-laden cells or has some pathophysiological effects on the progression of atheroma. Macrophages release various biologically active substances when they are activated by phagocytic particles such as zymosan A or inflammatory stimuli such as lipopolysaccharides (15). Among those substances, the products derived from arachidonate metabolism have attracted increasing attention, since recent studies have indicated their close relation to atherogenesis (16-19). However, little is known yet about arachidonate metabolism during the process of receptor-mediated incorporation of lipoproteins by macrophages and foam cell transformation. Investigation on this line, therefore, would be of some value, inasmuch as it might give us a clue for determining the functional role of the foam cells as to whether they act as a promotor for atheromatous formation (20).

In this study we incubated mouse peritoneal macrophages with lipoproteins and examined production of arachidonate metabolites with gas chromatography-mass spectrometry (GC/MS) and radioimmunoassay (RIA). We report that oxidized LDL stimulates arachidonate metabolism in macrophages during its incorporation into the cells.

\section{Methods}

\section{Materials}

$\left[5,6,8,11,12,14,15-{ }^{3} \mathrm{H}(\mathrm{N})\right]$ prostaglandin $\mathrm{E}_{2}\left(\mathrm{PGE}_{2}\right)(100-200 \mathrm{Ci} /$ $\mathrm{mmol}),\left[14,15-{ }^{3} \mathrm{H}(\mathrm{N})\right]$ leukotriene $\mathrm{C} 4\left(\mathrm{LTC}_{4}\right)(20-60 \mathrm{Ci} / \mathrm{mmol})$,

1. Abbreviations used in this paper: acetyl-LDL, acetylated LDL; $\beta$ VLDL, beta-migrating VLDL; GC/MS, gas chromatography-mass spectrometry; ir-PGE ${ }_{2}$, immunoreactive $\mathrm{PGE}_{2} ; \mathrm{MDA}$, malodialdehyde; TBARS, thiobarbituric acid-reactive substances. 
$\left[1-{ }^{14} \mathrm{C}\right.$ ]arachidonic acid $(40-60 \mathrm{mCi} / \mathrm{mmol}), \mathrm{Na}^{125} \mathrm{I}(17.4 \mathrm{Ci} / \mathrm{mg})$, and an LTC $_{4}{ }^{3} \mathrm{H}$-RIA kit were obtained from New England Nuclear (Boston, MA). Balb/3T3 clone A31 cells (catalog no. 03-415) were obtained from Flow Laboratories (Mclean, VA). Fetal calf serum (FCS) (catalog no. 14-5018) and calf serum (catalog no. 382-02) obtained from $M$. A. Bioproducts (Walkersville, MD) and the Research Foundation for Microbial Disease of Osaka University (Osaka, Japan), respectively, were heat-inactivated at $56^{\circ} \mathrm{C}$ for $30 \mathrm{~min}$ before use. Dulbecco's modified Eagle's medium (DME) and Dulbecco's phosphate-buffered saline (PBS) were purchased from Nissui Seiyaku (Tokyo, Japan). L-Glutamine and penicillin-streptomycin were obtained from Flow Laboratories (North Ryde, New South Wales, Australia) and Gibco Laboratories (Chagrin Falls, $\mathrm{OH}$ ), respectively. Fucoidin, zymosan A, and cytochalasin B were obtained from Sigma Chemical Co. (St. Louis, MO). $\mathrm{CuSO}_{4}$ and EDTA were obtained from Nakarai Chemicals (Kyoto, Japan). Standard $\mathrm{PGE}_{2}, \mathrm{PGD}_{2}, \mathrm{PGF}_{2 \alpha}$, 6-keto-PGF $1 \alpha$, and antiserum to $\mathrm{PGE}_{2}$ were kind gifts from Ono Pharmaceutical (Osaka, Japan). Plastic petri dishes were obtained from Nunc (Roskilde, Denmark). A Lipoperoxide test kit was obtained from Wako Chemicals (Osaka, Japan). All other chemicals used were of reagent grade.

\section{Cells}

Macrophages. Peritoneal cells were harvested from unstimulated female DDY mice (25-30 g) in PBS as described by Edelson et al. (21) and Kita et al. (7). The peritoneal perfusates from 20-40 mice were pooled and the cells, 3-6 $\times 10^{6}$ cells per mouse, were collected by centrifugation at $400 \mathrm{~g}$ at $4^{\circ} \mathrm{C}$ for $10 \mathrm{~min}$. After being washed once with $30 \mathrm{ml}$ of PBS, the cells were resuspended in the culture medium, DME containing $10 \%$ (vol/vol) FCS, penicillin $(100 \mathrm{U} / \mathrm{ml})$, and streptomycin $(100 \mu \mathrm{g} / \mathrm{ml})$, at a final density of $3 \times 10^{6} \mathrm{cells} / \mathrm{ml}$. Aliquots ( 1 $\mathrm{ml})$ were dispersed on to plastic petri dishes $(35 \times 10 \mathrm{~mm})$ and the cells were cultured in humidified air containing $5 \% \mathrm{CO}_{2}$ at $37^{\circ} \mathrm{C}$. After $2 \mathrm{~h}$, each dish was washed twice with $2 \mathrm{ml}$ of DME without serum to remove nonadherent cells. After the cells were cultured for another 18 h at $37^{\circ} \mathrm{C}$ in $1 \mathrm{ml}$ of the culture medium, they were washed with $1 \mathrm{ml}$ of DME without FCS and used for the experiment. The experiment was initiated by adding various amounts of lipoproteins or other reagents in $1 \mathrm{ml}$ of the culture medium, and incubation was carried out under conditions described above for the indicated time periods. Zymosan $(80 \mathrm{mg}$ ) was boiled for $30 \mathrm{~min}$ in PBS and then incubated with $4 \mathrm{ml}$ of mouse serum for $30 \mathrm{~min}$ at $37^{\circ} \mathrm{C}$. After being washed twice with PBS, zymosan was finally resuspended in $4 \mathrm{ml}$ of PBS and added to the culture medium to a final concentration of $50 \mu \mathrm{g} / \mathrm{ml}$. Cytochalasin B, prepared as a stock solution of $1.0 \times 10^{-2} \mathrm{M}$ in dimethylsulfoxide (DMSO), was added to the culture medium to a final concentration of $1 \times 10^{-4} \mathrm{M}$ with lipoproteins. After the medium was removed from each dish at the end of incubation for determination of arachidonate metabolites, the cells were washed with $2 \mathrm{ml}$ of PBS twice and received $1.0 \mathrm{ml}$ of $0.2 \mathrm{~N} \mathrm{NaOH}$. After overnight incubation, $50-\mu \mathrm{l}$ aliquots were used for measurement of protein contents with bovine serum albumin as a standard according to the methods of Lowry et al. (22).

$3 T 3$ cells. 3T 3 cells were plated at a density of $9.6 \times 10^{4}$ cells $/ \mathrm{ml}$ in $1 \mathrm{ml}$ of DME containing $10 \%$ (vol/vol) calf serum, penicillin (100 $\mathrm{U} / \mathrm{ml})$, and streptomycin $(100 \mu \mathrm{g} / \mathrm{ml})$ on plastic petri dishes $(35 \times 10$ $\mathrm{mm}$ ) and maintained in humidified air containing $5 \% \mathrm{CO}_{2}$ at $37^{\circ} \mathrm{C}$. On day 4 of culture the cells were washed with $1 \mathrm{ml}$ of DME without serum, and various amounts of lipoproteins in the culture medium were added. Measurements of arachidonate metabolites and cellular protein contents were performed as described for macrophages.

\section{Lipoproteins}

Plasma was obtained from 14-d fasting Japanese white rabbits (3.0-3.5 $\mathrm{kg}$ ) prepared with EDTA as an anticoagulant $(7,9,23,24)$, and LDL ( $d$ $=1.019-1.063 \mathrm{~g} / \mathrm{ml}$ ) was isolated by ultracentrifugation (25) and dialyzed against two changes of at least $500 \mathrm{vol}$ of $10 \mathrm{mM}$ sodium phosphate buffer, $\mathrm{pH} 7.4$, containing $150 \mathrm{mM} \mathrm{NaCl}$. $\beta$-VLDL was isolated from Japanese white rabbits fed a $2 \%$ cholesterol-10\% corn oil diet for $14 \mathrm{~d}(7,9)$. Acetyl-LDL was prepared from LDL of healthy human subjects by the method described by Basu et al. (26). For preparation of oxidized LDL, $5.0 \mathrm{mg}$ of protein from rabbit LDL was suspended in 2 $\mathrm{ml}$ of PBS containing $5 \mu \mathrm{M} \mathrm{CuSO}_{4}$ and was incubated at $37^{\circ} \mathrm{C}$ for $40 \mathrm{~h}$ in a $\mathrm{CO}_{2}$ incubator. $\mathrm{LDL}$ within $14 \mathrm{~d}$ of isolation was used for oxidation.

For all experiments native LDL, acetyl-LDL, $\beta$-VLDL, and oxidized LDL were filtered through a $0.45-\mu \mathrm{m}$ filter (Millipore Japan, Tokyo, Japan). The recovery of protein and lipid peroxides determined as thiobarbituric acid-reactive substances (TBARS) was 70-80\% during filtration.

\section{HPLC and electrophoresis of lipoproteins}

Lipoproteins (50-100 $\mu \mathrm{g}$ of protein) were applied to the gel permeation columns (TSK GEL, G5000PW + G3000SW; Toyo Soda, Tokyo, Japan) following the method described by Okazaki et al. (27). The experimental conditions were as follows: temperature of the separation columns, $4^{\circ} \mathrm{C}$; eluent, $150 \mathrm{mM}$ Tris $\mathrm{Cl}$, $\mathrm{pH} \mathrm{7.4;} \mathrm{flow} \mathrm{rate,} 0.20 \mathrm{ml} / \mathrm{min}$. Detection of peaks was carried out by measuring cholesterol in the eluate from the column by the bioreactor-type detection system with cholesterol esterase and cholesterol oxidase, which were immobilized on TSK GEL G6000PW (Toyo Soda) (28). To the inlet of the bioreactor column was introduced the staining fluid composed of peroxidase, 4-aminoantipyrine, $N$-ethyl- $N$-(2-hydroxy-3-sulfopropyl)-m-toluidine, and Triton $\mathrm{X}-100$. Using these reagents, cholesterol can be measured by the absorbance at $550 \mathrm{~nm}$ of the quinone diimine dye. The experimental conditions of the enzymatic reactions were as follows: temperature of the reactor, $40^{\circ} \mathrm{C}$; flow rate of the staining fluid; $0.1 \mathrm{ml} / \mathrm{min}$. Recovery for lipoproteins as determined by cholesterol content was more than $95 \%$ after passage through the HPLC system.

Agarose gel electrophoresis of lipoproteins was carried out as described by Nobel (29).

\section{Electron microscopy of lipoproteins}

Electron microscopy of negatively stained lipoproteins was performed as described by Forte et al. (30). In brief, LDL filtered through a $0.45-\mu \mathrm{m}$ filter was dialyzed against $500 \mathrm{vol}$ of $3 \mathrm{mM}$ sodium phosphate buffer, $\mathrm{pH} 7.4$, and then mixed with the same volume of $2 \%$ sodium phosphotungstate, $\mathrm{pH} 7.2$, to make the final concentration of $250 \mu \mathrm{g}$ of protein $/ \mathrm{ml}$. A small aliquot of the mixture was overlayed on a Formvar-carbon-coated grid and was examined under a electron microscope (Hitachi H-7000).

\section{Assay for lipid peroxides}

Lipid peroxide formation was estimated as TBARS using a Lipoperoxide test kit according to the methods of Heinecke et al. (12) and Yagi (31) with a slight modification. LDL ( $50 \mu \mathrm{g}$ of protein) was suspended in $1.5 \mathrm{ml}$ of $150 \mathrm{mM} \mathrm{NaCl}$, and the suspension was mixed with $0.5 \mathrm{ml}$ of $20 \%$ trichloroacetic acid (TCA) and $0.5 \mathrm{ml}$ of TBA reagent $(0.67 \%$ TBA aqueous solution/glacial acetic acid, 1:1, vol/vol) and boiled at $95^{\circ} \mathrm{C}$ for $60 \mathrm{~min}$. The mixture was cooled with water and shaken vigorously with $2.0 \mathrm{ml}$ of $n$-butanol for at least $15 \mathrm{~s}$. After centrifugation at $4,000 \mathrm{~g}$ for $10 \mathrm{~min}$, the $n$-butanol layer was removed, and the fluorescence was measured on a Hitachi fluorescence spectrophotometer (No. 650-60, Hitachi, Tokyo, Japan) with excitation at $515 \mathrm{~nm}$ and emission at $550 \mathrm{~nm}$. Tetramethoxypropane was used as a standard and results were expressed as nmol of malondialdehyde (MDA) equivalents.

\section{Extraction and radioimmunoassay of $P G E_{2}$ and $L T C_{4}$}

At the end of the incubation, the medium was removed and applied to extraction. After $\left[{ }^{3} \mathrm{H}\right] \mathrm{PGE}_{2}$ or $\left[{ }^{3} \mathrm{H}\right] \mathrm{LTC}_{4}, 3,000-4,000 \mathrm{cpm}$, was added, the samples were applied to a SEP-PAK C18 cartridge (Waters Associates, Milford, MA) as described by Powell (32) with a slight modification. The $\mathrm{PGE}_{2}$ - and $\mathrm{LTC}_{4}$-like immunoreactivities were eluted from the cartridges with ethyl acetate and methanol, respectively. The ethyl acetate fraction was evaporated and the dried residue was dissolved in $1 \mathrm{ml}$ of $50 \mathrm{mM}$ Tris-Cl, $\mathrm{pH} 7.4$, and used for RIA (33). The recovery of the $\mathrm{PGE}_{2}$ internal standard was $60-70 \%$. Methanol 
fraction was also evaporated, and the dried residue was used for RIA with an $\mathrm{LTC}_{4}{ }^{3} \mathrm{H}$-RIA kit (34). The recovery of the $\mathrm{LTC}_{4}$ internal standard in the final sample was $75-80 \%$.

For thin-layer chromatography of $\mathrm{PGE}_{2}$ immunoreactivity extracted from culture medium, aliquots of the extract dissolved in ethyl acetate were applied to $20 \times 20$-cm silica gel plates, and the plates were developed with the solvent, ethyl acetate/acetic acid (98:2, vol/vol). After development the plate was air-dried and the silica gel between the front and the origin was evenly divided into 14 fractions. $\mathrm{PGE}_{2}$ immunoreactivity was extracted from each fraction with ethyl acetate. The extracts were evaporated with $\mathrm{N}_{2}$ and then used for RIA of PGE 2 . Authentic $\mathrm{PGE}_{2}, \mathrm{PGF}_{2 \alpha}$ and $\mathrm{PGD}_{2}$ were applied to the silica gel plates on a separate lane as standard markers.

\section{Study on macrophages prelabeled with}

\section{$\left[1-{ }^{14} \mathrm{C}\right.$ ]arachidonic acid}

A macrophage monolayer $\left(3 \times 10^{6}\right.$ cells $)$ was incubated with $0.85 \mu \mathrm{Ci}$ of $\left[1-{ }^{14} \mathrm{C}\right]$ arachidonic acid in $1 \mathrm{ml}$ of DME containing $10 \%$ FCS. After $18 \mathrm{~h}$, the cells were washed twice with $1 \mathrm{ml}$ of DME and incubated with $1 \mathrm{ml}$ of DME containing various additions. After $6 \mathrm{~h}$, the medium was collected and applied to a SEP-PAK C18 cartridge as described above. PGs were eluted with $10 \mathrm{ml}$ of ethyl acetate. $8 \mathrm{ml}$ of the ethyl acetate fraction was evaporated and the residue dissolved in $100 \mu \mathrm{l}$ of ethyl acetate was applied to the silica gel thin layer as described above. After development the plate was air-dried and the radioactivity at the $\mathrm{PGE}_{2}$ position was measured. The rest $(2 \mathrm{ml})$ of the ethyl acetate fraction was evaporated and the dried residue was used for RIA for $\mathrm{PGE}_{2}$. The specific radioactivity for $\left[{ }^{14} \mathrm{C}\right] P \mathrm{PGE}_{2}$ was determined and corrected with $\left[{ }^{3} \mathrm{H}\right] \mathrm{PGE}_{2}$ added as an internal standard.

\section{Assays of cholesterol reacylation and the degradation of ${ }^{125} I-L D L$}

Reacylation of cholesterol was measured as an incorporation of $\left[{ }^{14} \mathrm{C}\right]$ oleate $(5 \mathrm{mCi} / \mathrm{mmol})$ into cellular cholesteryl oleate by cell monolayers as described by Brown et al. (5) except that culture was performed without FCS (7). The degradation of ${ }^{125}$ I-labeled lipoproteins by macrophage monolayer was measured as described by Goldstein et al. (4) and Kita et al. (7).

\section{Derivatization and $G C / M S$}

$\left[{ }^{2} \mathrm{H}_{4}\right] \mathrm{PGE}{ }_{2}, \mathrm{PGD}_{2}, \mathrm{PGF}_{2 \alpha}, 6-k$ eto-PGF ${ }_{1 \alpha}$, and $\mathrm{TxB}_{2}$ (40 ng each) were added to a medium as internal standards. Extraction was performed as described above. After evaporation of ethyl acetate, methylation was carried out by treatment of a sample with diazomethane in methanol. After purification by SEP-PAK C18 cartridge, methyl esters were treated with a saturated solution of methoxamine hydrochloride in pyridine at $60^{\circ} \mathrm{C}$ for $1 \mathrm{~h}$. Dimethylisopropylsilyl imidazole was then added to a reaction mixture and the solution was allowed to stand at room temperature for another hour. The reaction mixture was applied on a Sephadex LH-20 Column $(5 \times 0.8 \mathrm{~cm})$ and the final derivative was eluted with $2.8 \mathrm{ml}$ of $\mathrm{CHCl}_{3} / n$-hexane/methanol, 10:10:1 (vol/ vol/vol). After evaporation the residue was dissolved in $n$-hexane containing $1 \%$ (vol/vol) pyridine and used for GC/MS as described by Miyazaki et al. (35).

GC/MS was carried out with a JEOL DX $300 \mathrm{GC} /$ mass spectrometer (JEOL Ltd., Tokyo) with a data processing system. The column employed was a thermostable cross-linked OV-1 fused silica capillary column ( $25 \mathrm{~m} \times 0.31 \mathrm{~mm}$ i.d., Hewlett Packard Co., Palo Alto, CA), and helium was used as a carrier gas with an inlet pressure of 0.4 $\mathrm{kg} / \mathrm{cm}^{2}$. The column temperature was maintained isothermal at $265^{\circ} \mathrm{C}$ and samples were applied via a Van den Berg-type solventless injector. The ionization energy and accelerating voltage were $70 \mathrm{eV}$ and $2.5 \mathrm{kV}$, respectively. $\mathrm{PGE}_{2}, \mathrm{PGD}_{2}, \mathrm{PGF}_{2 \alpha}, 6-$ keto- $\mathrm{PGF}_{1 \alpha}$, and $\mathrm{TxB}_{2}$ were quantified by peaks at $\mathrm{m} / \mathrm{Z} 552,552,625,670,670$, respectively. Quantifications of these PGs were corrected on the basis of recovery of the internal standards, which were monitored at $\mathrm{m} / \mathrm{Z} 556,556,629$, 674, and 674 for $\left[{ }^{2} \mathrm{H}_{4}\right] \mathrm{PGE}_{2}, \mathrm{PGD}_{2}, \mathrm{PGF}_{2 \alpha}, 6-$ keto-PGF $1 \alpha$, and $\mathrm{TxB}_{2}$, respectively.
Gel filtration of oxidized $L D L$

A PD-10 column (Pharmacia Fine Chemicals, Uppsala Sweden) was equilibrated with PBS at $4^{\circ} \mathrm{C}$, and $2.5 \mathrm{mg}$ of protein from oxidized LDL suspended in $1 \mathrm{ml}$ of PBS was loaded and eluted with $20 \mathrm{ml}$ of PBS. Fractions $(1.0 \mathrm{ml})$ were collected and 10 - and $25-\mu$ laliquots were used for measurement of protein contents and for TBARS assay, respectively.

\section{Analysis of data}

The values shown represent mean $\pm \mathrm{SE}$ and statistical significance was determined by Student's $t$ test.

\section{Results}

Physicochemical properties of oxidized $L D L$. We first examined the gel permeation behavior of our preparations of oxidized LDL by using HPLC. As shown in Fig. 1, a major peak was found at the volume of $28.5 \mathrm{ml}$, which was a position identical with that of native LDL. In addition, a small shoulder was found at $24.4 \mathrm{ml}$ in the uprising of this major peak. Calibration of the column showed that this shoulder represents particle(s) larger than VLDL but smaller than $\beta$-VLDL. We next examined the morphological profile of native and oxidized LDL particles under electron microscopy. As shown in Fig. $2 A$, native LDL particles were uniform in size and shape. The diameter was $22 \pm 4 \mathrm{~nm}$. On the other hand, as shown in Fig. $2 B$, the oxidized LDL preparation contained particles of two different types. One particle type had almost the same size as that of native LDL and the other was enlarged and of uneven shape. The diameter of the enlarged particles was $91 \pm 17$ $\mathrm{nm}$, almost equivalent to the minimal size of chylomicron

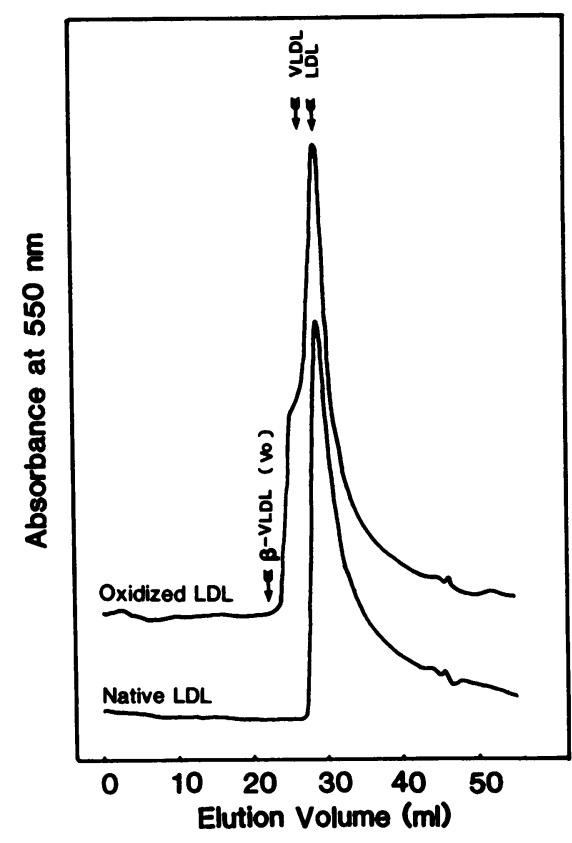

Figure 1. Gel permeation chromatography of native and oxidized LDL. Oxidized LDL was obtained by incubating rabbit LDL with $\mathrm{Cu}^{2+}$ at $37^{\circ} \mathrm{C}$ for $40 \mathrm{~h}$. Oxidized LDL and native LDL (50-100 $\mu \mathrm{g}$ of protein) were applied to TSK GEL columns (G5000PW+G3000SW). Chromatography was performed at $4^{\circ} \mathrm{C}$ at a constant flow of $0.20 \mathrm{ml} / \mathrm{min}$. Cholesterol content was measured by determination of the absorbance at $550 \mathrm{~nm}$. $\beta$-VLDL was eluted in the void volume (Vo). Other markers used are VLDL and LDL. 


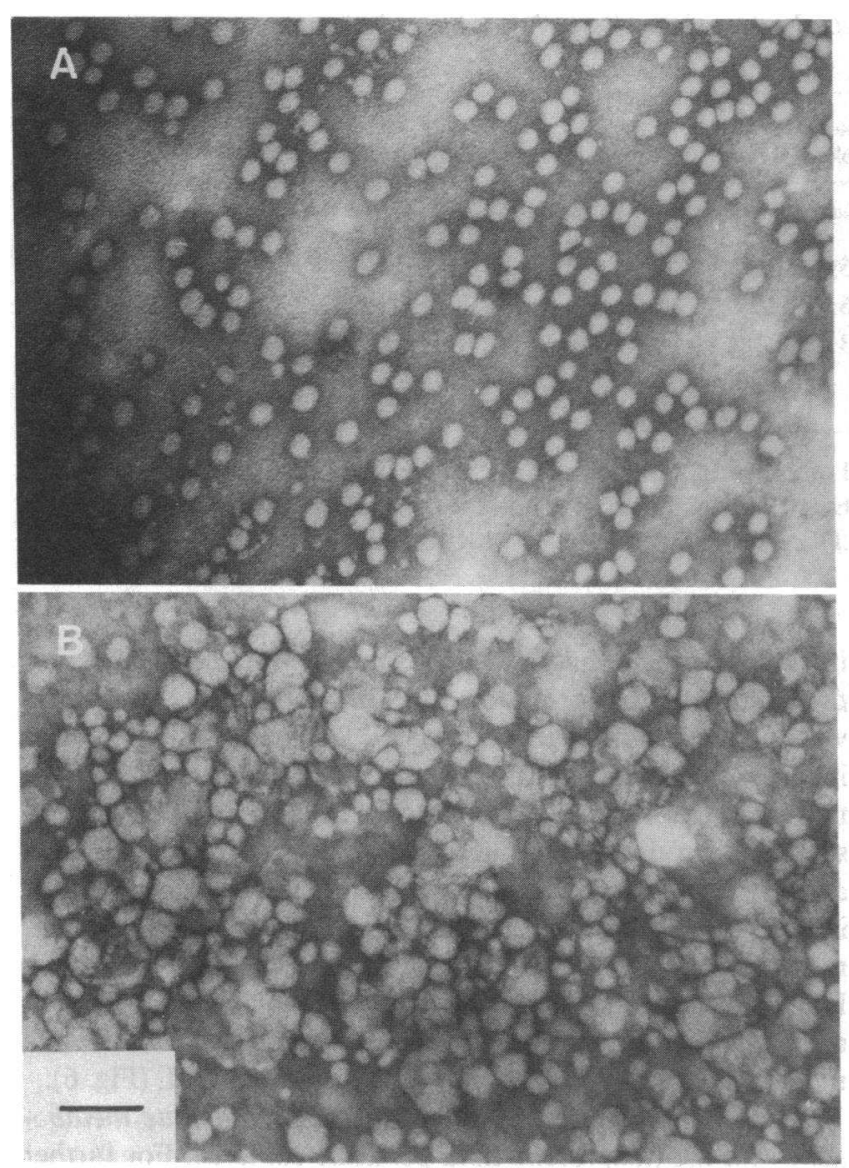

Figure 2. Transmission electron microscopy of $(A)$ native LDL and $(B)$ oxidized LDL. Lipoproteins were stained with $1 \%$ phosphotungstate, $\mathrm{pH}$ 7.2. Bar, $100 \mathrm{~nm}$.

remnants, i.e., $90 \mathrm{~nm}(36)$. These results indicate that enlargement of particles could occur during the oxidative modification of LDL. To investigate whether both the enlarged and native-sized particles were modified, we applied our preparation of oxidized LDL to agarose gel electrophoresis. As shown in Fig. 3, almost all the protein in our oxidized LDL preparation migrated more negatively than native LDL, suggesting that not only the enlarged particle but also the particle with native-sized diameter underwent oxidative modification.

Stimulation of macrophage $P G E_{2}$ synthesis by oxidized $L D L$. As shown in Table I, TBARS content in the oxidized LDL preparation characterized above was $32.80 \pm 2.10 \mathrm{nmol}$ $\mathrm{MDA} / \mathrm{mg}$ protein, which was 13.7 -fold higher than that in native LDL (2.41 \pm 0.32 ). Consistent with previous reports ( 11 , 12), our preparation of oxidized LDL was incorporated by macrophages about 10 -fold more efficiently than by native LDL. We incubated macrophages with these preparations of lipoproteins and investigated the changes in arachidonate metabolism in the cells. We measured immunoreactive $\mathrm{PGE}_{2}$ (ir$\mathrm{PGE}_{2}$ ) biosynthesis by macrophages during incubation with native and oxidized LDL. When macrophages were incubated with native $\mathrm{LDL}(90 \mu \mathrm{g} / \mathrm{ml})$, no increase in ir- $\mathrm{PGE}_{2}$ production was detected; ir-PGE ${ }_{2}$ formations with and without LDL were $78.2 \pm 5.3$ and $75.1 \pm 8.4 \mathrm{ng} / \mathrm{mg}$ cellular protein per $6 \mathrm{~h}$, respectively. In contrast, when macrophages were incubated with oxidized LDL, ir-PGE ${ }_{2}$ biosynthesis was much elevated. The formation was $397.0 \pm 12.7 \mathrm{ng} / \mathrm{mg}$ cellular protein per $6 \mathrm{~h}$, which was 5.3 -fold higher than the control $(P<0.01)$. To exclude the possibility that $\mathrm{Cu}^{2+}$ in the oxidized $\mathrm{LDL}$ fraction stimulated arachidonate metabolism, we incubated macrophages with $2 \mu \mathrm{M} \mathrm{Cu}^{2+}$ instead of oxidized LDL. No enhanced production of ir-PGE 2 was observed, i.e., $76.2 \pm 4.5 \mathrm{ng} / \mathrm{mg}$ cellular protein per $6 \mathrm{~h}$. When native LDL was preincubated in PBS without $\mathrm{Cu}^{2+}$, no increase in TBARS formation nor stimulatory effect on ir-PGE 2 synthesis was detected. We also examined the effect of human LDL on macrophage ir-PGE synthesis. Oxidized human LDL $(90 \mu \mathrm{g} / \mathrm{ml})$ also stimulated ir- $\mathrm{PGE}_{2}$ production to an extent similar to that of oxidized rabbit LDL, although native human LDL had no effect (data not shown). In order to assess specificity of our RIA, we added indomethacin to the culture medium and followed ir-PGE biosynthesis by macrophages. Formation of ir-PGE ${ }_{2}$ was completely inhibited by $10 \mu \mathrm{g} / \mathrm{ml}$ indomethacin. We next subjected the medium extract to thin-layer chromatography as described in Methods. Immunoreactivity was observed only at the position identical with authentic $\mathrm{PGE}_{2}$ (data not shown).

Elevation in $\mathrm{PGE}_{2}$ biosynthesis in the cells incubated with oxidized LDL was also observed by the GC/MS analysis of cyclooxygenase metabolites, and $\mathrm{PGE}_{2}$ contents measured were comparable with those obtained by RIA (Table II). Enhanced production was also detected in 6-keto-PGF ${ }_{1 \alpha}$, a stable metabolite of prostacyclin ( $\mathrm{PGI}_{2}$ ), although the extent was less than that of $\mathrm{PGE}_{2}$. We also measured formation of 6-keto$\mathrm{PGF}_{1 \alpha}$ with RIA and the value was comparable to that by GC/MS (data not shown). No significant stimulation was observed on synthesis of $\mathrm{PGD}_{2}, \mathrm{PGF}_{2}$, or thromboxane $\mathrm{B}_{2}\left(\mathrm{TxB}_{2}\right)$.

When macrophages were incubated with oxidized LDL, $\mathrm{PGE}_{2}$ synthesis increased in a time-dependent curve (Fig. $4 \mathrm{~A}$ ). $\mathrm{PGE}_{2}$ synthesis increased almost linearly within a few hours after contact and continued to increase up to $12 \mathrm{~h}$. This time course was similar to that of incorporation of oxidized LDL into the cells (data not shown). As shown in Fig. $4 \mathrm{~B}$, this stimulatory effect was dose dependent on protein contents of oxidized LDL. PGE 2 synthesis was linear up to $180 \mu \mathrm{g}$ of protein from oxidized $\mathrm{LDL} / \mathrm{ml}$; the $\mathrm{PGE}_{2}$ biosynthesis at 180 $\mu \mathrm{g}$ of protein $/ \mathrm{ml}$ was $813 \pm 123 \mathrm{ng} / \mathrm{mg}$ cellular protein per $6 \mathrm{~h}$, 10.8-fold higher than the control.

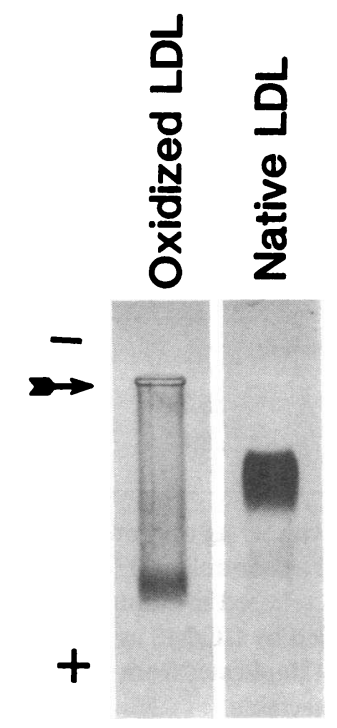

Figure 3. Agarose gel electrophoresis of native LDL and oxidized LDL. Lipoproteins (50-100 $\mu \mathrm{g}$ of protein) were applied to $0.5 \%$ agarose gel electrophoresis and stained with Fat Red 7B. The site of application is shown by the arrow. 
Table I. Effects of Preincubation of LDL with $\mathrm{Cu}^{2+}$ on TBARS Contents, Incorporation Rates into Macrophages, and Stimulatory Effect on Macrophage PGE, Synthesis

\begin{tabular}{|c|c|c|c|c|}
\hline & TBARS contents & $\begin{array}{l}\text { Incorporation of }\left[{ }^{14} \mathrm{C}\right] \text { oleate } \\
\text { into cholesteryl ester }\end{array}$ & Macrophage $\mathrm{PGE}_{2}$ synthesis & $\begin{array}{l}\text { Protein contents of } \\
\text { remaining cells }\end{array}$ \\
\hline & nmol MDA/mg protein & nmol/mg cellular protein per $6 h$ & $n g / m g$ cellular protein per $6 h$ & $\mu g$ of protein per dish \\
\hline None (control) & - & $0.15 \pm 0.05$ & $75.1 \pm 8.4$ & $80.6 \pm 7.7$ \\
\hline Native LDL & $2.41 \pm 0.32$ & $0.96 \pm 0.58$ & $78.2 \pm 5.3 \mathrm{NS}$ & $93.6 \pm 18.4 \mathrm{NS}$ \\
\hline Oxidized LDL & $32.80 \pm 2.10^{*}$ & $9.33 \pm 0.80^{*}$ & $397.0 \pm 12.7^{\ddagger}$ & $80.0 \pm 13.2 \mathrm{NS}$ \\
\hline LDL preincubated without $\mathrm{Cu}^{2+}$ & $2.45 \pm 0.31 \mathrm{NS}$ & - & $75.7 \pm 6.5 \mathrm{NS}$ & - \\
\hline
\end{tabular}

Macrophage monolayer, $6 \times 10^{6}$ cells, was incubated for $6 \mathrm{~h}$ with $90 \mu \mathrm{g} / \mathrm{ml}$ of native LDL, oxidized LDL, and LDL preincubated for $40 \mathrm{~h}$ without $\mathrm{Cu}^{2+}$. TBARS contents, incorporation rates, and effect on macrophage $\mathrm{PGE}_{2}$ synthesis of $\mathrm{LDL}$ were determined as described in Methods. Values represent mean \pm SE. ${ }^{*} P<0.01$ compared with native LDL. ${ }^{\ddagger} P<0.01$ compared with control.

To examine whether the stimulation of oxidized LDL on macrophage $\mathrm{PGE}_{2}$ production was correlated with cellular injury, the cells attached to the dish were dissolved with $0.2 \mathrm{~N}$ $\mathrm{NaOH}$ at the end of incubation and the protein contents of the extracts were measured. In contrast to the dramatic effect on $\mathrm{PGE}_{2}$ biosynthesis, oxidized LDL caused no decrease in cellular protein contents at the end of a 6-h incubation compared with native LDL or control $(80.0 \pm 13.2,93.6 \pm 18.4,80.6 \pm 7.7$ $\mu \mathrm{g}$ per dish, respectively) (Table I). We also examined microscopically the appearance of the cells stained with trypan blue. Less than $1 \%$ of the total cells were stained and there was no difference between the ratio of the stained cells in culture with and without lipoproteins.

Stimulatory effect of oxidized LDL on macrophage $L T C_{4}$ synthesis. When incubated with oxidized LDL $(90 \mu \mathrm{g}$ of protein/ml), macrophages synthesized and released $\mathrm{LTC}_{4}$ about three times more than the control culture $(29.7 \pm 15.3$ and $8.3 \pm 4.6 \mathrm{ng} / \mathrm{mg}$ cellular protein per $6 \mathrm{~h}$, respectively). The stimulatory effect was dose dependent on protein contents of oxidized LDL; $\mathrm{LTC}_{4}$ formation at the concentration of $180 \mu \mathrm{g}$ of protein/ml was 10.7-fold higher than the control, $89.5 \pm 29.5$ $\mathrm{ng} / \mathrm{mg}$ cellular protein per $6 \mathrm{~h}$. No stimulatory effect on $\mathrm{LTC}_{4}$ synthesis was observed in native LDL (Fig. 5).

Specificity of lipoproteins on the stimulation of arachidonate metabolism. In order to investigate whether the stimulatory effect of oxidized LDL on arachidonate metabolism was correlated with endocytotic incorporation of the lipoproteins

Table II. GC/MS Analysis of Various Prostaglandins Formed by Macrophages

\begin{tabular}{lrrrrr}
\hline & \multicolumn{5}{c}{ Prostaglandins formed by macrophages } \\
\cline { 2 - 5 } & $\mathrm{PGE}_{2}$ & $\mathrm{PGD}_{2}$ & $\mathrm{PGF}_{2 \alpha}$ & 6-keto-PGF & $\mathrm{TxB}_{2}$ \\
\hline & \multicolumn{5}{c}{ ng per sample } \\
Oxidized LDL & 29.9 & $\mathrm{ND}$ & 5.4 & 16.7 & $\mathrm{ND}$ \\
Control & 9.6 & $\mathrm{ND}$ & 6.7 & 8.8 & $\mathrm{ND}$ \\
& & & & & \\
\hline
\end{tabular}

Macrophages, $3 \times 10^{6}$ cells, were incubated with $90 \mu \mathrm{g}$ of protein $/ \mathrm{ml}$ of oxidized LDL or without LDL (designated as control) at $37^{\circ} \mathrm{C}$ for $6 \mathrm{~h}$. After incubation, various prostaglandins released in culture medium was extracted, derivatized, and quantified by GC/MS as described in Methods. Values are the average of duplicates from a representative of two experiments. ND, not detectable. in general, macrophages were incubated with acetyl-LDL and $\beta$-VLDL, and the formation of $\mathrm{PGE}_{2}$ and $\mathrm{LTC}_{4}$ by the cells was followed. Although both acetyl-LDL and $\beta$-VLDL were incorporated by the cells more efficiently than oxidized LDL, neither of them had any stimulatory effect on $\mathrm{PGE}_{2}$ biosynthesis; $\mathrm{PGE}_{2}$ production by macrophage during incubation with acetyl-LDL or $\beta$-VLDL was significantly less than the control, i.e., $42.1 \pm 6.8$ and $51.5 \pm 9.4 \mathrm{ng} / \mathrm{mg}$ cellular protein per $6 \mathrm{~h}$, respectively $(P<0.05)$. Neither of them caused any increase in LTC $_{4}$ synthesis, 8.4 and $9.3 \mathrm{ng} / \mathrm{mg}$ cellular protein per $6 \mathrm{~h}$, respectively. TBARS contents in acetyl-LDL or $\beta$-VLDL were not significantly different from those in native LDL (Fig. 6).

Association of stimulatory effect on arachidonate metabolism with the lipoprotein-lipid peroxide complex. For further elucidation of the stimulatory effect of oxidized LDL on arachidonate metabolism, oxidized LDL was applied to gel filtration as described in Methods, and elution of TBARS and protein contents were followed. As shown in Fig. 7, two peaks of
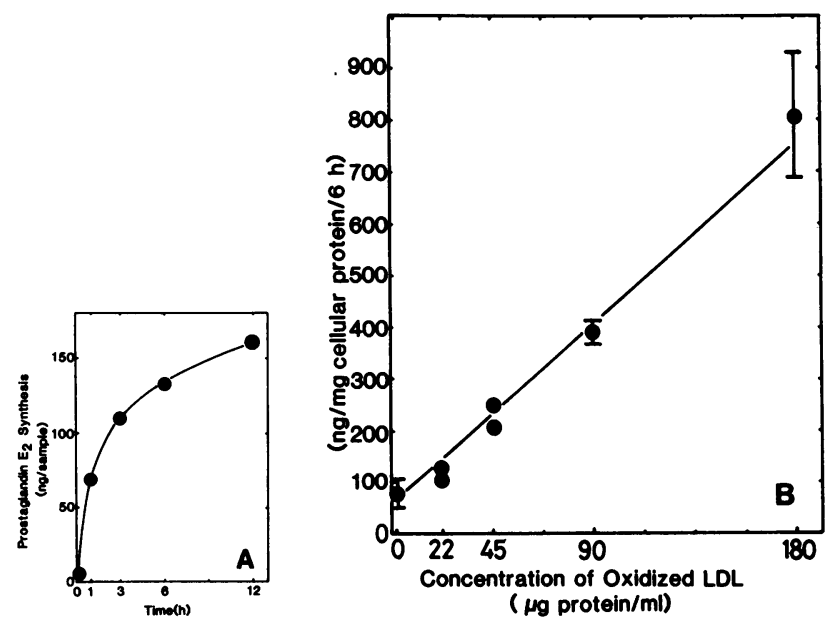

Figure 4. Time course and dose response of stimulation of macrophage $\mathrm{PGE}_{2}$ synthesis by oxidized LDL. $(A)$ Macrophage monolayer, $6 \times 10^{6}$ cells, was incubated with $90 \mu \mathrm{g}$ of protein $/ \mathrm{ml}$ of oxidized LDL. After incubation for indicated time, media were taken from dishes and the amount of $\mathrm{PGE}_{2}$ was determined by RIA. Values are the average of duplicates from a representative of two experiments. $(B)$ Macrophages, $6 \times 10^{6}$ cells, were incubated with indicated concentration of oxidized LDL at $37^{\circ} \mathrm{C}$ for $6 \mathrm{~h}$. $\mathrm{PGE}_{2}$ amounts were determined by RIA. Values represent mean \pm SE of four experiments. 


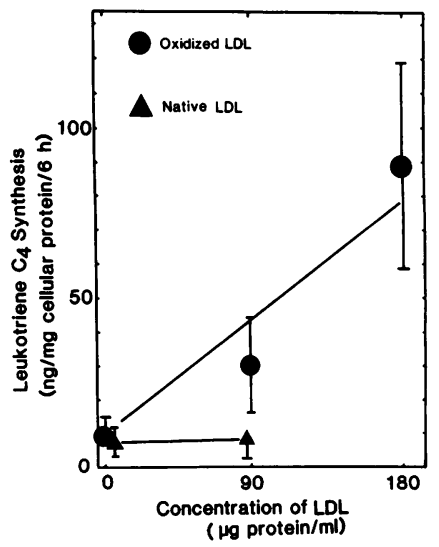

Figure 5. Stimulatory effect of oxidized LDL on macrophage $\mathrm{LTC}_{4}$ biosynthesis. Macrophage monolayer, $6 \times 10^{6}$ cells, was incubated with various concentrations of oxidized $\mathrm{LDL}$ or native $\mathrm{LDL}$ at $37^{\circ} \mathrm{C}$ for $6 \mathrm{~h}$. After incubation $\mathrm{LTC}_{4}$ amounts in the medium were determined by RIA. Values are mean \pm SE of three experiments.

TBARS were detected, those of fraction A (nos. 2-4) and fraction B (nos. 7-9), and a protein peak was observed only in fraction A. Thus fractions A and B were considered as the lipoprotein-lipid peroxide complex and free lipid peroxides, respectively. The TBARS level in fraction A was 13.2 \pm 1.5 $\mathrm{nmol} \mathrm{MDA} / \mathrm{mg}$ protein, $40.2 \pm 4.6 \%$ of that in unfractionated oxidized LDL. We incubated macrophages with various concentrations of either fraction A or B to elucidate which fraction was more responsible for the stimulation of macrophage arachidonate metabolism. As shown in Fig. 8, fraction A stimulated $\mathrm{PGE}_{2}$ synthesis in dose-dependent way. At the concentration of $2.4 \mathrm{nmol} \mathrm{MDA} / \mathrm{ml}(180 \mu \mathrm{g}$ protein $/ \mathrm{ml})$, the stimulatory effect of fraction A on $\mathrm{PGE}_{2}$ synthesis was $724.5 \mathrm{ng} / \mathrm{mg}$ cellular protein per $6 \mathrm{~h}$. This stimulation was $\sim 88 \%$ of that caused by unfractionated LDL containing the same protein contents, i.e., $813 \mathrm{ng} / \mathrm{mg}$ cellular protein per $6 \mathrm{~h}$. On the other hand, the stimulatory effect of fraction B was $<15 \%$ of that of fraction A, i.e., $194.3 \pm 26.5 \mathrm{ng} / \mathrm{mg}$ cellular protein per $6 \mathrm{~h}(P$ $<0.05$ v.s. control). Stimulation by fraction A and B was not enhanced in the medium without FCS.

In order to determine whether the stimulatory action of fraction A was associated with incorporation by the cell, we incubated macrophages with cytochalasin B, an inhibitor of receptormediated incorporation of lipoproteins (37), and examined the changes in the rate of cholesterol reacylation and $\mathrm{PGE}_{2}$ formation in macrophages. Cytochalasin $\mathrm{B}\left(1 \times 10^{-4} \mathrm{M}\right)$ almost completely inhibited incorporation of $\left[{ }^{14} \mathrm{C}\right]$ oleate into cholesteryl oleate and reduced stimulation by fraction A on macrophage $\mathrm{PGE}_{2}$ synthesis by $91 \%$. When macrophages were incubated with $90 \mu \mathrm{g} / \mathrm{ml}$ fraction $\mathrm{A}$, cholesterol reacylation rates with and without cytochalasin $B$ were 0.75 and 12.5 $\mathrm{nmol} / \mathrm{mg}$ cellular protein per $6 \mathrm{~h}$, respectively, and increases in macrophage $\mathrm{PGE}_{2}$ formations were 35.0 and $405.0 \mathrm{ng} / \mathrm{mg}$ cellular protein per $6 \mathrm{~h}$, respectively. Cytochalasin B had no inhibitory effect on basal $\mathrm{PGE}_{2}$ formation, i.e., $90.2 \mu \mathrm{g} / \mathrm{mg}$ cellular protein per $6 \mathrm{~h}$. To test whether stimulatory effect of fraction A was associated with the acetyl-LDL receptor-mediated endocytosis, we examined the inhibitory effect of an excessive amount of acetyl-LDL on the degradation of fraction $A$ by the macrophage monolayer. When the cells were incubated with $90 \mu \mathrm{g} / \mathrm{ml}{ }^{125} \mathrm{I}$-labeled fraction A and $900 \mu \mathrm{g} / \mathrm{ml}$ acetyl-LDL, the degradation rate was suppressed by $55 \%$. The stimulatory effect of $90 \mu \mathrm{g} / \mathrm{ml}$ fraction A on $\mathrm{PGE}_{2}$ synthesis was not significantly suppressed by the addition of $900 \mu \mathrm{g} / \mathrm{ml}$ acetyl-LDL; $\mathrm{PGE}_{2}$ formations at the presence or absence of acetyl-LDL in these experiments were 256.5 and $267.0 \mathrm{ng} / \mathrm{mg}$ cellular protein per $6 \mathrm{~h}$, respectively. However, we could not definitely exclude involvement of acetyl-LDL receptor pathway in stimulation of $\mathrm{PGE}_{2}$ formation, since acetyl-LDL at this concentration caused increase in $\mathrm{PGE}_{2}$ formation, i.e., $130.1 \mu \mathrm{g} / \mathrm{mg}$ cellular protein per $6 \mathrm{~h}$, almost twice as the control level, i.e., $67.5 \mu \mathrm{g} / \mathrm{mg}$ cellular protein per $6 \mathrm{~h}$. We also examined the effect of either $100 \mu \mathrm{g} / \mathrm{ml}$ fucoidin, a specific inhibitor of acetyl-LDL receptor, or $40 \mu \mathrm{M}$ chloroquine, a lysosomal inhibitor $(1,4,5)$, on the stimulation of arachidonate metabolism in the cells by fraction A. Both of the reagents, however, potently stimulated arachidonate metabolism by themselves.

Study on macrophages prelabeled with $\left[{ }^{14} \mathrm{C}\right]$ arachidonate. In order to determine the source of arachidonate released on the stimulation by oxidized LDL, we labeled the cells with $\left[1-{ }^{14} \mathrm{C}\right]$ arachidonate as described in Methods and then stimulated them with either fraction A or zymosan. When macrophages were stimulated with $90 \mu \mathrm{g} / \mathrm{ml}$ fraction $\mathrm{A}$, the specific radioactivity of $\mathrm{PGE}_{2}$ formed was not significantly decreased from the value in the control experiments with no additions, i.e. $1,032 \pm 299$ or $1,268 \pm 425 \mathrm{dpm} / \mathrm{ng} \mathrm{PGE}_{2}(n=4)$, respectively. Nor was it different from that found in macrophages stimulated by $50 \mu \mathrm{g} / \mathrm{ml}$ zymosan A, i.e., $1,346 \pm 299 \mathrm{dpm} / \mathrm{ng}$ $\mathrm{PGE}_{2}(n=4)$.

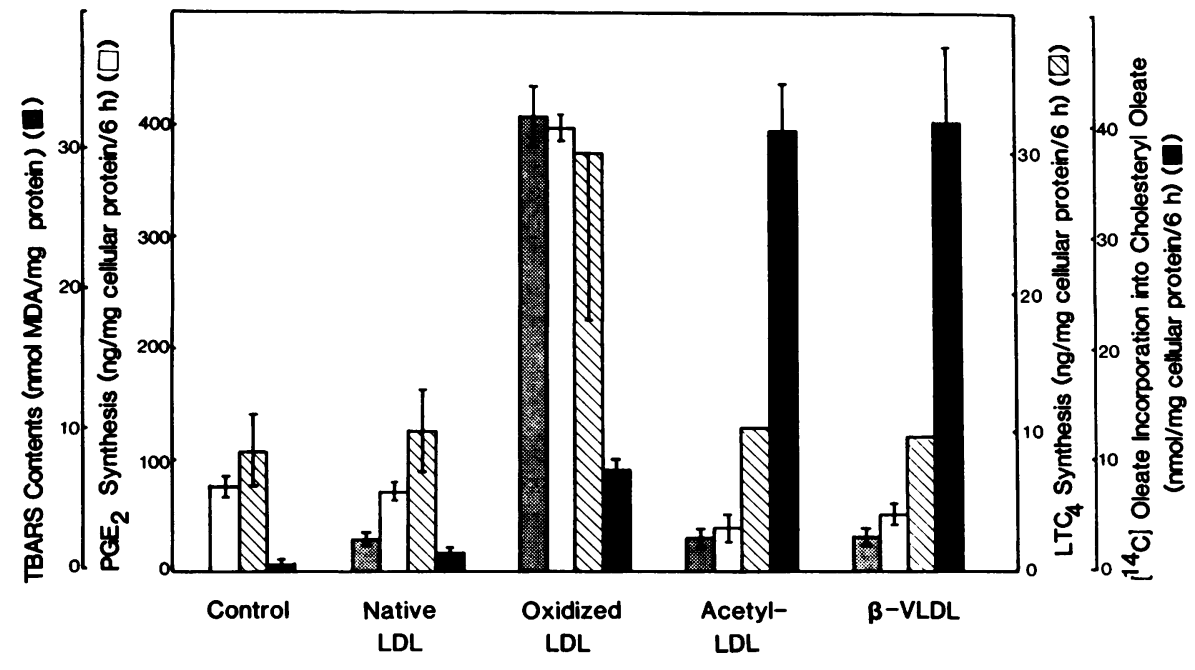

Figure 6. TBARS contents, effect on $\mathrm{PGE}_{2}$ and $\mathrm{LTC}_{4}$ synthesis, and incorporation rates into macrophages of various lipoproteins. Macrophage monolayer, $6 \times 10^{6}$ cells, was incubated with $90 \mu \mathrm{g} / \mathrm{ml}$ of oxidized LDL, native LDL, acetyl-LDL, and $\beta$-VLDL at $37^{\circ} \mathrm{C}$ for $6 \mathrm{~h}$. Assay for TBARS contents was carried out as described in Methods. After incubation, amounts of $\mathrm{PGE}_{2}$ and $\mathrm{LTC}_{4}$ were measured by RIA. Control represents incubation without lipoprotein. Assessment of incorporation of $\left[{ }^{14} \mathrm{C}\right]$ oleate into cholesteryl ester was carried out as described in Methods. 


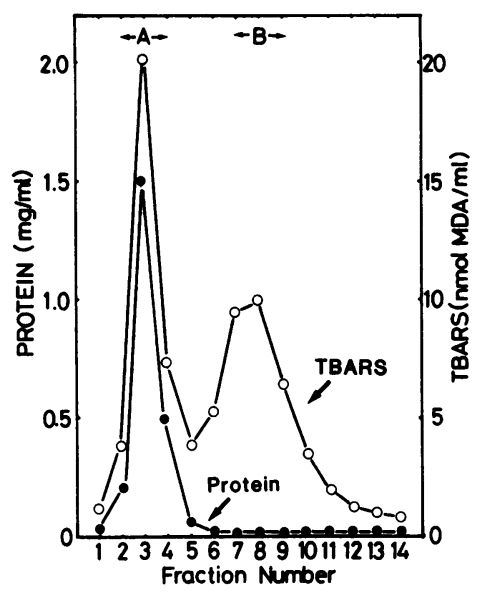

Specificity of cell species on the stimulatory effects of oxidized LDL on arachidonate metabolism. In order to examine the specificity of cell species sensitive to the stimulatory effect of oxidized LDL on arachidonate metabolism, the 3T3 cell monolayer was incubated with native and oxidized LDL. Oxidized LDL stimulated cholesteryl ester formation in 3T3 cells about twofold more than native LDL; the rates of cholesterol reacylation in the control and during incubation with $90 \mu \mathrm{g} / \mathrm{ml}$ native LDL and oxidized LDL were 10.3, 10.2, and 24.1 $\mathrm{nmol} / \mathrm{mg}$ cellular protein per $6 \mathrm{~h}$, respectively. However, oxidized LDL had no stimulatory effect on $\mathrm{PGE}_{2}$ synthesis by these cells. Native LDL had no stimulatory effect either. The formation of $\mathrm{PGE}_{2}$ was less than $10 \mathrm{ng} / \mathrm{mg}$ cellular protein per $6 \mathrm{~h}$, whether the cells were incubated with or without lipoproteins.

\section{Discussion}

In this study we have shown that oxidized LDL was not only incorporated by macrophages but also stimulated arachidonate metabolism (Table I). The stimulatory effect of oxidized LDL on $\mathrm{PGE}_{2}$ synthesis by macrophages occurred in both a dose- and time-dependent manner (Fig. 4, $A$ and $B$ ). In addition to $\mathrm{PGE}_{2}$, oxidized LDL stimulated macrophage $\mathrm{LTC}_{4}$ synthesis (Fig. 5). Native LDL was taken up by macrophages at a very low rate and had no stimulatory effect on arachidonate metabolism (Table I, Fig. 5).

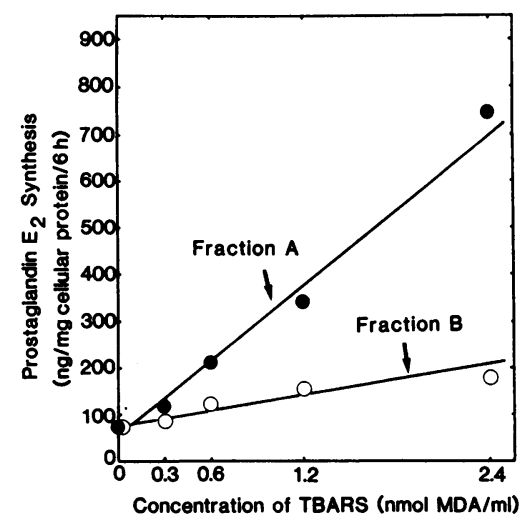

Figure 8. Dose response of macrophage $\mathrm{PGE}_{2}$ biosynthesis by fractions A and B. After filtering through a $0.45-\mu \mathrm{m}$ filter, indicated TBARS concentrations of fractions $A(\bullet)$ and $B$ (O) were added to the macrophage monolayer $\left(6 \times 10^{6}\right.$ cells $)$. After $6 \mathrm{~h}$ of incubation PGE 2 amounts were determined by RIA. The recovery for TBARS in

fractions A and B after filtration were $78 \%$ and $95 \%$, respectively. Values are the average of duplicates from a representative of four experiments.
Since the scavenger pathway in macrophages for modified LDL was revealed in vitro, LDL modification has been proposed to play an important role in atheroma formation in vivo. Oxidized LDL is now considered to be a candidate for naturally occurring modified LDL, as lipid peroxides have been suggested to be closely correlated with initiation and progression of atheroma (14). Peroxidized lipids have been demonstrated to accumulate in atherosclerotic lesions (13) and to cause injuries on the vascular tissues (38). Quinn et al. have reported that oxidized LDL has inhibitory effect on the endothelial cell-derived chemotactic activity for mouse peritoneal macrophages (39). In addition, Parthasarathy et al. (40) have also reported that probucol, a known inhibitor of both progression of atherosclerotic lesion and xanthoma formation (41), could block oxidative modification of LDL at the concentration lower than the plasma levels of the patients during ordinary treatment. Heinecke et al. (42) have shown that superoxide released from arterial smooth muscle cells enhances $\mathrm{Cu}^{2+}$. or $\mathrm{Fe}^{2+}$-catalyzed modification of LDL. Cathcart et al. (43) have also reported that incubation with monocytes and neutrophils leads to oxidation of LDL. If oxidized LDL could be produced in the body, it would be incorporated rapidly by macrophages and stimulate arachidonate metabolism thereby inducing enhanced release of $\mathrm{PGE}_{2}$ and $\mathrm{LTC}_{4}$.

Since oxidized LDL is reported by some authors to have a cytotoxic effect on certain cell types including endothelial cells and fibroblasts $(10,43-46)$, we examined whether the stimulation of arachidonate metabolism was correlated with cellular injury. In our study, however, no evidence of cellular injury on the macrophage monolayer was observed within $12 \mathrm{~h}$, neither the decrease in cellular protein contents (Table I), nor that in viable cells, excluding trypan blue, was found.

In our study we have demonstrated that major stimulatory activity on arachidonate metabolism exists in the lipoproteinlipid peroxide complex, and not in free lipid peroxides (Fig. 8). Steinberg and his collaborators reported that peroxidation of LDL is accompanied with degradation of phosphatidylcholine into lysophosphatidylcholine and suggested possible release of free fatty acids $(11,47)$. Since FCS is known to trap free fatty acids in the medium, we examined the stimulatory effect of fraction B in DME without FCS. Our results, however, showed that the stimulatory effect of fraction B on arachidonate metabolism was not enhanced under these conditions. Thus it is hardly possible that unsaturated fatty acids liberated from phospholipids of LDL during its peroxidation should participate as substrate for prostaglandin or leukotriene cascade.

In this study we have also shown that some of oxidized LDL particles could become enlarged severalfold in diameter (Figs. 1, 2, $A$ and $B$, and 3). Previous studies suggest that oxidized LDL is recognized and incorporated via the acetylLDL receptor of macrophages $(11,48,49)$. In our results, however, acetyl-LDL suppressed the degradation of ${ }^{125} \mathrm{I}$-oxidized LDL by macrophages only by $55 \%$ and did not suppress oxidized LDL-induced $\mathrm{PGE}_{2}$ formation completely. Our preliminary experiments showed that the binding of ${ }^{125}$ I-oxidized LDL to the surface of macrophage and its degradation by the cell were almost completely suppressed by an excessive amount of unlabeled oxidized LDL, while unlabeled acetylLDL was less potent as a competitive inhibitor (unpublished observation). Thus, we could not exclude the existence of other receptors which are also responsible for this incorporation. It would be natural, therefore, that stimulation of $\mathrm{PGE}_{2}$ 
synthesis could not be inhibited completely by an excessive amount of acetyl-LDL. At present it is not known whether such multiplicity of receptor for oxidized LDL corresponds to the heterogenous population of this modified LDL.

Macrophages are known to release arachidonate metabolites when activated by phagocytic stimuli (50-53). In this situation, cytochalasin B augments prostaglandin synthesis by macrophages stimulated by the particles, although it inhibits phagocytotic incorporation of phagocytosed particles $(54,55)$. These observations are contrary to our results. In our experiments, cytochalasin B suppressed both incorporation of oxidized LDL and stimulation of $\mathrm{PGE}_{2}$ synthesis by the cell. Moreover, stimulation of macrophage arachidonate metabolism by phagocytosis reaches plateau within $1 \mathrm{~h}$ after the stimuli (56), while in our experiments release of arachidonate metabolite from the cell increased gradually and continued to increase up to $12 \mathrm{~h}$ after contact. This time course was similar to that of incorporation of oxidized LDL by the cells. These findings suggest that the process through which oxidized LDL stimulated macrophage arachidonate metabolism is distinct from that with phagocytosis and that receptor-mediated incorporation of lipoprotein particle could be prerequisite for the stimulatory effect.

What was noteworthy in our study was that acetyl-LDL and $\beta$-VLDL, both of which were incorporated by macrophages by receptor-mediated endocytosis more efficiently than oxidized LDL, had little stimulatory effect on arachidonate metabolism (Fig. 6). These results indicate that the receptormediated endocytosis of lipoprotein particle in general is not associated with activation of macrophage arachidonate metabolism. Inasmuch as acetyl-LDL and $\beta$-VLDL had no increased TBARS contents (Fig. 6), incorporation of the lipoprotein particle with peroxidative modification would play a primary role in stimulation of arachidonate metabolism in macrophages.

Pomerantz et al. (57) reported that HDL and LDL could stimulate arachidonate metabolism in vascular smooth muscle cells by providing arachidonate for the pools sensitive to cyclooxygenase. However, in our experiments, when macrophage was labeled with $\left[{ }^{14} \mathrm{C}\right]$ arachidonate and then stimulated with unlabeled fraction $A$, the specific radioactivity of $P G E_{2}$ formed was not decreased significantly from that observed in the control experiments. These results suggest that the stimulatory effect of oxidized LDL on macrophage arachidonate metabolism is not induced by introduction of arachidonate into the cells but could be due to activation of phospholipase $A_{2}$ or other enzymes in the arachidonate cascade by the incorporated lipoprotein-lipid peroxide complex. Our suggestions are consistent with the report by Weglicki et al. (58), who described that activation of phospholipase $A_{2}$ was induced by free radicals derived from lipid peroxides. Our working hypothesis is depicted in Fig. 9. Such a mechanism appears to be restricted to macrophages, since oxidized LDL failed to stimulate 3T3 cells to synthesize $\mathrm{PGE}_{2}$.

$\mathrm{PGE}_{2}$, among the products of arachidonate metabolism, has been known to have the most active proinflammatory effects especially in the early stage, such as extensive vasodilation, enhancement of vasopermeability, and potentiation of pain caused by bradykinin or histamine (53). In contrast, $\mathrm{LTC}_{4}$ is recognized as a potent vasoconstrictor for arteries and is known to induce an increase in vascular permeability, inducing plasma exudation (59). In addition to the effects on

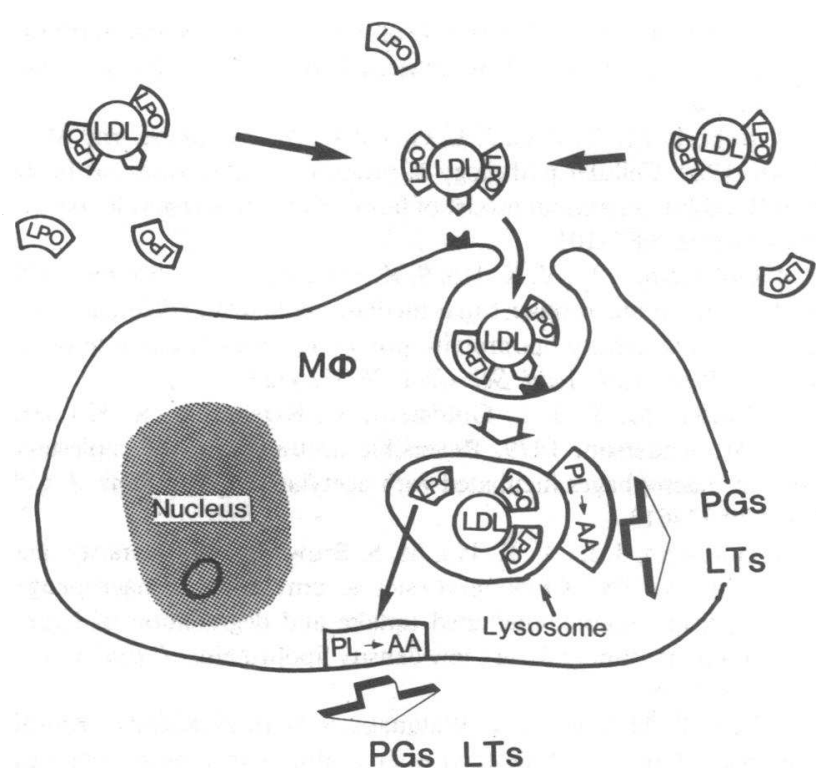

Figure 9. Proposed mechanism for stimulation of arachidonate metabolism in macrophage by oxidized LDL. AA, arachidonic acid; PL, phospholipid; LPO, lipid peroxides.

inflammatory response, a growing body of evidence indicates that lipoxygenase products play a role as a promotor of atheromatous formation (59-61). Once these events could take place in arterial walls, they would induce infiltration of more amounts of plasma LDL into the subendothelial space and facilitate the vascular injury, eventually leading further to vasospasm and progression of atheroma.

These findings indicate that oxidized LDL could induce progression of atheroma by stimulating arachidonate metabolism in macrophages. These events could occur in the body, since several lines of evidence indicate that oxidized LDL may be an analogue for the lipoproteins accumulated in the vessel walls. Our results would be of importance in elucidating the role of macrophages and the modification of LDL in atherogenesis.

\section{Acknowledgments}

The authors thank Miss Chiri Lanphere for reading and correcting our manuscript. We are grateful to Nippon Shinyaku Co. Ltd. for the supply of animals in our experiments, and to Ono Pharmaceuticals for the generous gifts of authentic $P G$ s and $P E_{2}$ antiserum. We thank Dr. Keisuke Makino for performing HPLC of lipoproteins and also thank Dr. Satoru Murayama for performing electron microscopy of lipoproteins.

This work was supported in part by Grants-in-Aid for Scientific and Cancer Research from the Ministry of Education, Science and Culture of Japan (Nos. 60010104, 60214020, 6057013, 61132003, 61219012 , and 61480250), and grants from the Japanese Foundation on Metabolism and Diseases, the Takeda Science Foundation, and the Suzuken Memorial Foundation.

\section{References}

1. Brown, M. S., and J. L. Goldstein. 1983. Lipoprotein metabolism in the macrophage: implications for cholesterol deposition in atherosclerosis. Annu. Rev. Biochem. 52:223-261. 
2. Gerrity, R. G. 1981. The role of the monocyte in atherogenesis. II. Migration of foam cells from atherosclerotic lesions. Am. J. Pathol. 103:191-200.

3. Buja, L. M., T. Kita, J. L. Goldstein, Y. Watanabe, and M. S. Brown. 1983. Cellular pathology of progressive atherosclerosis in the WHHL rabbit: an animal model of familial hypercholesterolemia. $A r-$ teriosclerosis. 3:87-101.

4. Goldstein, J. L., Y. K. Ho, S. K. Basu, and M. S. Brown. 1979. Binding site on macrophages that mediates uptake and degradation of acetylated low density lipoprotein, producing massive cholesterol deposition. Proc. Natl. Acad. Sci. USA. 76:333-337.

5. Brown, M. S., J. L. Goldstein, M. Krieger, Y. K. Ho, and R. G. W. Anderson. 1979. Reversible accumulation of cholesteryl esters in macrophages incubated with acetylated lipoproteins. J. Cell Biol. 82:597-613.

6. Goldstein, J. L., Y. K. Ho, M. S. Brown, T. L. Innerarity, and R. W. Mahley. 1980. Cholesteryl ester accumulation in macrophages resulting from receptor-mediated uptake and degradation of hypercholesterolemic canine $\beta$-very low density lipoproteins. J. Biol. Chem. 255:1839-1848.

7. Kita, T., M. Yokode, Y. Watanabe, S. Narumiya, and C. Kawai. 1986. Stimulation of cholesteryl ester synthesis in mouse peritoneal macrophages by cholesterol-rich very low density lipoproteins from the Watanabe Heritable Hyperlipidemic Rabbit, an animal model of familial hypercholesterolemia. J. Clin. Invest. 77:1460-1465.

8. Goldstein, J. L., T. Kita, and M. S. Brown. 1983. Defective lipoprotein receptors and atherosclerosis: lessons from an animal counterpart of familial hypercholesterolemia. N. Engl. J. Med. 309:288-296.

9. Kita, T., M. S. Brown, Y. Watanabe, and J. L. Goldstein. 1981. Deficiency of low density lipoprotein receptors in liver and adrenal gland of the WHHL rabbit, an animal model of familial hypercholesterolemia. Proc. Natl. Acad. Sci. USA. 78:2268-2272.

10. Morel, D. W., P. E. DiCorleto, and G. M. Chisolm. 1984. Endothelial and smooth muscle cells alter low density lipoprotein in vitro by free radical oxidation. Arteriosclerosis. 4:357-364.

11. Steinbrecher, U. P., S. Parthasarathy, D. S. Leake, J. L. Witztum, and D. Steinberg. 1984. Modification of low density lipoprotein by endothelial cells involves lipid peroxidation and degradation of low density lipoprotein phospholipids. Proc. Natl. Acad. Sci. USA. 81:3883-3887.

12. Heinecke, J. W., H. Rosen, and A. Chait. 1984. Iron and copper promote modification of low density lipoprotein by human arterial smooth muscle cells in culture. J. Clin. Invest. 74:1890-1894.

13. Glavind, J., S. Hartmann, J. Clemmesen, K. E. Jessen, and H. Dam. 1952. Studies on the role of lipoperoxides in human pathology. II. The presence of peroxidized lipids in the atherosclerotic aorta. Acta. Pathol. Microbiol. Scand. 30:1-6.

14. Yagi, K. 1986. A biochemical approach to atherogenesis. Trends Biochem. Sci. 11:18-19.

15. Nathan, C. F., H. W. Murray, and Z. A. Cohn. 1980. The macrophage as an effector cell. N. Engl. J. Med. 303:622-626.

16. Vane, J. R., S. Bunting, and S. Moncada. 1982. Prostacyclin in physiology and pathophysiology. Int. Rev. Exp. Pathol. 23:161-207.

17. Larrue, J., M. Rigaud, D. Daret, J. Demond, J. Durand, and H. Bricaud. 1980. Prostacyclin production by cultured smooth muscle cells from atherosclerotic rabbit aorta. Nature (Lond.). 285:480-483.

18. Gryglewski, R. J., A. Dembiǹska-Kiec̀, A. Zmuda and T. Gryglewska. 1978. Prostacyclin and thromboxane $A_{2}$ biosynthesis capacities of heart, arteries and platelets at various stages of experimental atherosclerosis in rabbits. Atherosclerosis. 31:385-394.

19. Hajjar, D. P., B. B. Weksler, D. J. Falcone, J. M. Hefton, K. Tack-Goldman, and C. R. Minick. 1982. Prostacyclin modulates cholesteryl ester hydrolytic activity by its effect on cyclic adenosine monophosphate in rabbit aortic smooth muscle cells. J. Clin. Invest. 70:479-488.

20. Steinberg, D. 1983. Lipoproteins and atherosclerosis. A look back and a look ahead. Arteriosclerosis. 3:283-301.
21. Edelson, P. J., and Z. A. Cohn. 1976. Purification and cultivation of monocytes and macrophages. In in vitro methods in cell-mediated and tumor immunity. B. R. Bloom and J. R. David, editors. Academic Press, Inc., New York. 333-340.

22. Lowry, O. H., N. J. Rosenbrough, A. L. Farr, and R. J. Randall. 1951. Protein measurement with the Folin phenol reagent. J. Biol. Chem. 193:265-275.

23. Bilheimer, D. W., Y. Watanabe, and T. Kita. 1982. Impaired receptor-mediated catabolism of low density lipoprotein in the WHHL rabbit, an animal model of familial hypercholesterolemia. Proc. Natl. Acad. Sci. USA. 79:3305-3309.

24. Stoudemire, J. B., G. Renaud, D. M. Shames, and R. J. Havel. 1984. Impaired receptor-mediated catabolism of low density lipoproteins in fasted rabbits. J. Lipid Res. 25:33-39.

25. Havel, R. J., H. A. Eder, and J. H. Bragdon. 1955. The distribution and chemical composition of ultracentrifugally separated lipoproteins in human serum. J. Clin. Invest. 34:1345-1353.

26. Basu, S. K., J. L. Goldstein, R. G. W. Anderson, and M. S. Brown. 1976. Degradation of cationized low density lipoprotein and regulation of cholesterol metabolism in homozygous familial hypercholesterolemia fibroblasts. Proc. Natl. Acad. Sci. USA. 73:3178-3182.

27. Okazaki, M., K. Shiraishi, Y. Ohno, and I. Hara. 1981. Highperformance aqueous gel permeation chromatography of serum lipoproteins: selective detection of cholesterol by enzymatic reaction. $J$. Chromatogr. 223:285-293.

28. Sasaki, I., K. Makino, and T. Takeuchi. 1985. Use of Toyopearl as a support for the immobilization of urease. J. Chromatogr. 332:237-242.

29. Nobel, R. P. 1968. Electrophoretic separation of plasma lipoproteins in agarose gel. J. Lipid Res. 9:693-700.

30. Forte, T. M., and R. W. Nordhausen. 1986. Electron microscopy of negatively stained lipoproteins. Methods Enzymol. 128:442457.

31. Yagi, K. 1976. A simple fluorometric assay for lipoperoxide in blood plasma. Biochem. Med. 15:212-216.

32. Powell, W. S. 1982. Rapid extraction of arachidonic acid metabolites from biological samples using octadecylsilyl silica. Methods Enzymol. 86:467-477.

33. Ogorochi, T., S. Narumiya, N. Mizuno, K. Yamashita, H. Miyazaki, and O. Hayaishi. 1984. Regional distribution of prostaglandins $D_{2}, E_{2}$, and $F_{2}$ and related enzymes in postmortem human brain. J. Neurochem. 43:71-82.

34. Aehringhaus, U., R. H. Wölbling, W. König, C. Patrono, B. M. Peskar, and B. A. Peskar. 1982. Release of leukotriene $C_{4}$ from human polymorphonuclear leukocytes as determined by radioimmunoassay. FEBS (Fed. Eur. Biochem. Soc.) Lett. 146:111-114.

35. Miyazaki, H., M. Ishibashi, K. Yamashita, Y. Nishikawa, and M. Katori. 1981. Dimethylisopropylsilyl ether derivatives in gas chromatography mass spectrometry of prostaglandins and thromboxane B $_{2}$. Biomed. Mass Spectrom. 8:521-526.

36. Fainau, M., R. W. Mahley, R. L. Hamilton, and T. L. Innerarity. 1982. Structural and metabolic heterogeneity of $\beta$-very low density lipoproteins from colesterol-fed dogs and humans with type III hyperlipoproteinemia. J. Lipid Res. 23:702-714.

37. Miller, N. E., and J. A. Yin. 1978. Effects of cytochalasin B on low-density lipoprotein metabolism by cultured human fibroblasts. Biochim. Biophys. Acta. 530:145-150.

38. Yagi, K., H. Ohkawa, N. Ohishi, M. Yamashita, and T. Nakashima. 1981. Lesion of aortic intima caused by intravenous administration of linoleic acid hydroperoxide. J. Appl. Biochem. 3:58-65.

39. Quinn, M. T., S. Parthasarathy, and D. Steinberg. 1985. Endothelial cell-derived chemotactic activity for mouse peritoneal macrophages and the effects of modified forms of low density lipoprotein. Proc. Natl. Acad. Sci. USA. 82:5949-5953.

40. Parthasarathy, S., S. G. Young, J. L. Witztum, R. C. Pittman, and D. Steinberg. 1986. Probucol inhibits oxidative modification of low density lipoprotein. J. Clin. Invest. 77:641-644.

41. Yamamoto, A., Y. Matsuzawa, B. Kishino, R. Hayashi, K. 
Hirobe, and T. Kikkawa. 1983. Effects of probucol on homozygous cases of familial hypercholesterolemia. Atherosclerosis. 48:157-166.

42. Heinecke, J. W., L. Baker, H. Rosen, and A. Chait. 1986. Superoxide-mediated modification of low density lipoprotein by arterial smooth muscle cells. J. Clin. Invest. 77:757-761.

43. Cathcart, M. K., D. W. Morel, and G. M. Chisolm, III. 1985. Monocytes and neutrophils oxidize low density lipoprotein making it cytotoxic. J. Leukocyte Biol. 38:341-350.

44. Schuh, J., A. Novogrodsky, and R. H. Haschemeyer. 1978. Inhibition of lymphocyte mitogenesis by autoxidized low-density lipoprotein. Biochem. Biophys. Res. Comm. 84:763-768.

45. Hessler, J. R., D. W. Morel, L. J. Lewis, and G. M. Chisolm. 1983. Lipoprotein oxidation and lipoprotein-induced cytotoxity. Arteriosclerosis. 3:215-222.

46. Evensen, S. A., K. S. Galdal, and E. Nilsen. 1983. LDL-induced cytotoxicity and its inhibition by anti-oxidant treatment in cultured human endothelial cells and fibroblasts. Atherosclerosis. 49:23-30.

47. Parthasarathy, S., U. P. Steinbrecher, J. Barnett, J. L. Witztum, and D. Steinberg. 1985. Essential role of phospholipase $A_{2}$ activity in endothelial cell-induced modification of low density lipoprotein. Proc. Natl. Acad. Sci. USA. 82:3000-3004.

48. Henriksen, T., E. M. Mahoney, and D. Steinberg. 1981. Enhanced macrophage degradation of low density lipoprotein previously incubated with cultured endothelial cells: recognition by receptors for acetylated low density lipoproteins. Proc. Natl. Acad. Sci. USA. 78:6499-6503.

49. Henriksen, T., E. M. Mahoney, and D. Steinberg. 1982. Interactions of plasma lipoproteins with endothelial cells. Ann. N. Y. Acad. Sci. 401:102-116.

50. Bonney, R. J., and J. L. Humes. 1984. Physiological and pharmacological regulation of prostaglandin and leukotriene production by macrophages. J. Leukocyte Biol. 35:1-10.

51. Humes, J. L., R. J. Bonney, L. Pelus, M. E. Dahlgren, S. J. Sadowski, F. A. Kuhel, Jr., and P. Davies. 1977. Macrophages synthesize and release prostaglandins in response to inflammatory stimuli. Nature (Lond.). 269:149-151.
52. Rouzer, C. A., W. A. Scott, Z. A. Cohn, P. Blackburn, and J. M. Manning. 1980. Mouse peritoneal macrophages release leukotriene $C$ in response to a phagocytic stimulus. Proc. Natl. Acad. Sci. USA. 77:4928-4932.

53. Gemsa, D., H. G. Leser, M. Seitz, W. Deimann, and E. Bärlin. 1982. Membrane perturbation and stimulation of arachidonic acid metabolism. Mol. Immunol. 19:1287-1296.

54. Axline, S. G., and E. P. Reaven. 1974. Inhibition of phagocytosis and plasma membrane mobility of the cultivated macrophage by cytochalasin B: role of subplasmalemmal microfilaments. J. Cell Biol. 62:647-659.

55. Hsueh, W., C. Kuhn III, and P. Needleman. 1979. Relationship of prostaglandin secretion by rabbit alveolar macrophages to phagocytosis and lysosomal enzyme release. Biochem. J. 184:345-354.

56. Scott, W. A., J. M. Zrike, A. L. Hamill, J. Kempe, and Z. A. Cohn. 1980. Regulation of arachidonic acid metabolites in macrophages. J. Exp. Med. 152:324-335.

57. Pomerantz, K. B., A. R. Tall, S. J. Feinmark, and P. J. Cannon. 1984. Stimulation of vascular smooth muscle cell prostacyclin and prostaglandin $E_{2}$ synthesis by plasma high and low density lipoproteins. Circ. Res. 54:554-565.

58. Weglicki, W. B., B. F. Dickens, and I. T. Mak. 1984. Enhanced lysosomal phospholipid degradation and lysophospholipid production due to free radicals. Biochem. Biophys. Res. Commun. 124:229-235.

59. Feuerstein, G. 1984. Leukotrienes and the cardiovascular system. Prostaglandins. 27:781-802.

60. Van der Schroeff, J. G., L. Havekes, A. M. Weerheim, J. J. Emeis, and B. J. Vermeer. 1985. Supression of cholesteryl ester accumulation in cultured human monocyte-derived macrophages by lipoxygenase inhibitors. Biochem. Biophys. Res. Commun. 127:366372.

61. McIntyre, T. M., G. A. Zimmerman, and S. M. Prescott. 1986. Leukotrienes $\mathrm{C}_{4}$ and $\mathrm{D}_{4}$ stimulate human endothelial cells to synthesize platelet-activating factor and bind neutrophils. Proc. Natl. Acad. Sci. USA. 83:2204-2208. 